\title{
Displacement and education of the next generation: evidence from Bosnia and Herzegovina
}

\author{
Christoph Eder
}

Correspondence: christoph.eder@jku.at Department of Economics, Johannes Kepler University Linz, Altenberger Str. 69, 4040 Linz, Austria

\begin{abstract}
In this paper, I study the effect of displacement (in the sense of forced migration) of parents during a violent conflict on investment in their childrens' education years later. Using the ethnic division during the Bosnian War as a natural experiment, I plausibly identify exogenously displaced households and compare them to households who did not have to move because of the war. Displaced parents spend between 20 and 30\% less on the education of their children in primary and secondary school. The result also holds for single expenditure positions like textbooks, school materials and annual tuition in secondary school. A number of robustness checks and nearest-neighbor matching is performed to confirm the finding. A decomposition of the causal effect shows that differences in income and the stock of durable goods can at most explain one third of the finding. Potential explanations for the reduced spending of displaced parents on education include altered preferences through the exposure to violence, increased uncertainty about the future, and financial constraints.
\end{abstract}

JEL Classification: 125; J15; 015

Keywords: Displacement; Conflict; Education

\section{Introduction}

Violent conflict is a regular phenomenon in the developing world and its long-term consequences can be substantial through the destruction of human and physical capital, damage to infrastructure, and forced population movements. However, research on the economic consequences of wars and other violent events have only recently gained momentum as micro-level data from conflict areas become available. This is an important line of research as it indicates to policy makers the direct consequences of violent conflicts and which issues need to be dealt with once a conflict is over.

The findings in this literature offer interesting insights into peoples' lives in war-torn countries and on the effects of exposure to conflict. However, forced migration has seen relatively little attention, even though the UNHCR counts 10.4 million refugees and 36 million people of concern in 2009 in their Global Report (UNHCR 2009). In this paper I study the effects of displacement of parents on educational expenditure on their children. ${ }^{1}$

I use the ethnic division during the Bosnian War between 1992 and 1995 as a natural experiment for displacement. The war divided the previously ethnically mixed Bosnia and

(c) 2014 Eder; licensee Springer. This is an Open Access article distributed under the terms of the Creative Commons Attribution License (http://creativecommons.org/licenses/by/4.0), which permits unrestricted use, distribution, and reproduction in any medium, provided the original work is properly credited. 
Herzegovina into two parts and through "ethnic cleansing" resulted in two areas of homogeneous ethnic make-up. The resulting displacement of part of the population enables me to uncover its causal effects. The identification strategy circumvents the problem of endogenously migrated households by using only households who moved across the front line during the war. No significant difference in time invariant household characteristics support the assumption that treatment was exogenous.

The short time span between the end of the war and the collection of the data set does not allow me to evaluate educational outcomes of children of displaced parents. However, the education system of Bosnia and Herzegovina requires parents to provide textbooks, uniforms, school materials etc. to their children, which gives me the chance to look at inputs in educational production. In particular, I am interested in parents' education expenditure on their children.

I find that displaced parents spend significantly less on the education of their children five years after the end of the war than comparable households that were not displaced. The estimates of the reduction in spending on education range from 20 to $30 \%$. Considering that the average household in Bosnia and Herzegovina spends more than half a monthly household income on the education of a child per year, this is quantitatively a large difference. The finding is robust to a number of specifications and nearest-neighbor matching estimates confirm the magnitude. Displaced parents also spend significantly less on single expenditure positions like annual tuition in secondary school, textbooks, and other school materials.

Recent experimental evidence suggests that students' test scores react positively to additional educational inputs within a given institutional setting (Das et al. 2013), confirming an intuition that has been challenged in the past. ${ }^{2}$ As small an investment as $\$ 3$ per student spent mostly on child's stationary, classroom materials, and practice books can increase test scores by 0.1 standard deviations in India (Das et al. 2013). As Hanushek (2003) points out, there is evidence that increased school quality has positive effects on labor market outcomes and productivity.

Exploring the causal channels through which displacement influences education expenditure, I show that at most one third can be explained by differences in income and wealth levels. The employment status of parents also fails to explain a major part of the difference, so there is no evidence that displaced parents substitute school inputs for increased parental effort as found by Houtenville and Smith Conway (2008). Potential explanations for the reduced spending of displaced parents on education include altered preferences through exposure to violence, increased uncertainty about the future, and tighter financial constraints.

The paper is organized as follows: The next section reviews the literature, Section 3 discusses the background of the study in Bosnia and Herzegovina, as well as the data and the identification strategy, while Section 4 presents the main results. Section 5 discusses some channels through which displacement works and Section 6 concludes.

\section{Literature review}

The availability of micro-data from a large number of developing countries has greatly increased the possibilities of researchers to investigate the effects of violent conflicts at the individual and household level. A large number of papers look at the effects of exposure to violence on school attainment (eg. Akresh and de Walque 2008; Swee 2009; Shemyakina 
2011; Chamarbagwala and Morán 2009; Merrouche 2006; Rodriguez and Sanchez 2009). Most of these studies find a negative effect for at least a subgroup of the population even after the end of the violent spell. Justino (2011) surveys this literature. Swee (2009) analyzes the case of Bosnia and Herzegovina and finds lower completion rates in secondary school through exposure to a violent conflict. However, he argues the effect is driven by youth soldiering and should not have long-run consequences. Since displacement is a direct consequence of potential exposure to violence, my findings contribute to the understanding of why educational production is affected even after the end of the violence.

The destruction of schools during periods of violence often fails to explain the reduction in educational attainment as that would affect boys and girls in the same way, which is often not the case (Shemyakina 2011). Swee (2009) argues that youth soldering has prevented older males from attending school, while Shemyakina (2011) explains that girls were kept at home to avoid sexual assaults and harassment on their way to school. León (2012) finds evidence that the death of teachers and the health status of parents could be the causal mechanism.

In a recent addition to the literature Pivovarova and Swee (2012) suggest that all these findings could be driven by "selection into victimization", ie. wartime displacement changes the composition of the population. ${ }^{3}$ For the case of Nepal, Pivovarova and Swee (2012) show with panel data that the problem is empirically relevant.

Exposure to violence also has impacts on peoples' preferences. Bellows and Miguel (2009) find that it increases civil participation, while Voors et al. (2012) find that preferences towards risk, the discount rate, and altruistic behavior towards neighbors are affected.

The effects of displacement have also been studied in a number of papers. Fiala (2009) finds that displaced households have in general fewer assets and lower consumption quality. Only the previously poorest are marginally better off after displacement. Lower asset holdings of displaced households are also confirmed by Rahim et al. (2013). Kondylis (2010) shows that displacement makes men more likely to be unemployed and women more likely to be out of the labor force in the case of Bosnia and Herzegovina.

In the long-run Sarvimäki et al. (2009) find positive effects on income for displaced agricultural workers in Finland, which is confirmed by Bauer et al. (2013) for Germany. However, the latter find lower income for the rest of the displaced even for the second generation. The positive long-run effects of displacement found in Sarvimäki et al. (2009) and Bauer et al. (2013) are likely due to increased sector and geographic mobility of the displaced population. With the exception of Bauer et al. (2013), the above mentioned contributions focus on the effect on the generation of the displaced, however the negative consequences of displacement do not need to end there.

\section{Context, data, and identification}

\subsection{The Bosnian war}

Bosnia and Herzegovina became independent in the Fall of 1991 after the breakdown of former Yugoslavia. The three major ethnic groups, Bosniaks, Serbs, and Croats, were struggling to gain power and eventually the conflict turned violent in April 1992. Initially all three ethnic groups were fighting each other, with the Serbs in control of the army of the former Yugoslavia (Silber and Little 1996, p.222). In February 1994, Croats and 
Bosniaks reached a peace agreement and eventually joined forces against the Serbs. With air support from the NATO, Bosniaks and Croats were able to push the Serbs back and regain control of large areas. The Bosnian War ended in December 1995 with the Dayton Agreement, according to which Bosnia and Herzegovina was divided into two entities along the front line at the end of the war: the Federation of Bosnia and Herzegovina and the Republika Srpska. During the war about 100,000 - 110,000 people were killed and an estimated 1.3 - 1.8 mio. were displaced (the total population in 1991, the year of the last official census, was 4.38 mio.).

The extensive displacement during the war led to mostly ethnically homogeneous geographic areas. After the war most Bosniaks and Croats lived in the Federation of Bosnia and Herzegovina and most Serbs in the Republika Srpska. Those two entities are like separate states with their own administration and they currently cooperate only in a few areas. As Dahlman and Tuathail (2005) show with two examples, in ethnically mixed municipalities that were split between the two entities, the ethnic groups were almost completely segregated by 1998 along the entity borders, which was not the case before the war. However, the Dayton Agreement declares that all refugees and displaced persons have the right to return to their homes of origin and get their property returned (Tuathail and O'Loughlin 2009, p.1047). The return migration peaked in the years 2002-03, but a large fraction of the displaced population does not plan to return to their pre-war homes. Also the majority of the properties of displaced households in their home municipalities was occupied by others, destroyed, or damaged (Tuathail and O'Loughlin 2009, p.1051).

\subsection{The education system in Bosnia and Herzegovina}

The education system in Bosnia and Herzegovina faces many challenges and changes these days. As of 2001, primary education lasts for 8 years, where during the first 4 years the entire material is taught by one teacher and in grades 5-8 each subject has its own teacher. Secondary education is divided into vocational training and gymnasium (more academically oriented), where curricula are taught in 3-5 year programs (UNESCO 1996; UNESCO 1997). In general, primary schools have no annual tuition, but textbooks, school materials, etc. still need to be payed for by the parents. Only few municipalities ensure that textbooks for disadvantaged are provided (OECD 2006). Low or non-existent incomes, migration, and difficult post-war conditions are common reasons why parents are unable to be "active parents" and fail to provide school equipment, supplies, and textbooks (UNESCO 1996).

The post-war financial situation for schools in Bosnia and Herzegovina was constrained, to say the least, as this paragraph from a report about the education system in the Republika Srpska illustrates (UNESCO 1997, p.ii.):

"Primary education is, in theory, free, and is financed from the government budget. In practice the government is often unable to pay salaries, and school repairs have often become the responsibility of the municipal authorities. At the secondary level the central government is expected to pay the salaries of personnel, and the municipality all other charges. It was reported that in December 1996 public sector employees, including teachers, had not been paid for 4 to 5 months. The education system today is largely dependent on financial sacrifices made by teachers and families. Textbooks, 
for example, are extremely expensive: an average primary school text costing DM 1-3.4 $[\mathrm{DM}=$ Convertible Mark $]$ and a secondary one as much as DM 7".

Reports show that the curriculum for primary school is designed for a child equipped with 10 textbooks per grade. For most parents that seems hardly affordable, given that a qualified teacher earned in 1996 only 120 Convertible Mark per month (UNESCO 1996) and unemployment is high. ${ }^{4}$ In the years following the publication of these reports, some reforms concerning the curriculum took place and in 2004 primary school was extended to 9 years (Swee 2010). International aid has certainly improved some issues, but it is unclear if this reduced the parents' financial burden of having children in school. A project report on the education reform in Bosnia and Herzegovina by the European Union from 2008 observes (EU 2008): "The education reform process evolves at an uneven and slow pace".

\subsection{Data}

For this study I use household survey data from the "Living Standard Measurement Survey" (henceforth LSMS) (State Agency for Statistics of BiH et al. 2001) of Bosnia and Herzegovina. The data collection started in 2001 in 25 municipalities with about 5,400 households. From 2002-2004 about half of the households were reinterviewed each year to form a 4-year panel data set. The LSMS covers a wide range of topics. The different sections ask questions about housing, education, health, labor, credit, migration, and social assistance. There are also sections on consumption, household businesses, and agricultural activities. For most of this paper, I use the cross-sectional data from 2001. I do this for two reasons: First, the sample size is reduced in the panel data to half the number of households, and second, the 2002-2004 interviews cover a limited number of topics. I will go into more detail about data issues in the respective sections.

\subsection{Identification}

In order to seriously estimate an effect of displacement on household behavior, the treatment of displacement must be at random, ie. ex ante, households in both, treatment and control group, do not differ in their characteristics, neither observable nor unobservable. Given that displacement is a form of migration, this is a strict requirement to satisfy. In this section I argue that the Bosnian War provides a rare, although sad, opportunity to study this by-product of violent conflict. I think of displacement as a version of migration, where the instinct of self-preservation dominates all economic considerations. The single most important push-factor is survival, while pull-factors of certain destinations do not pose a problem to the estimation of a causal effect, as municipality fixed effects are always included in the regressions.

My identification strategy, in a nutshell, is that in Bosnia and Herzegovina ethnicities were mixed before the war. The Bosnian War introduced a line of division along which two ethnically homogeneous territories emerged. The front line was not drawn by economic motives and people did not sort themselves into displacement but were forced by their instinct of self-preservation. The random course of the line of division and the absence of self-selection allow me to identify the effect of displacement on household behavior by comparing households that crossed the front line to households that did not move during the war. 
At the time when Bosnia and Herzegovina was part of former Yugoslavia, the population was a mix of Bosniaks, Serbs, and Croats in most municipalities. The ethnic conflict in Bosnia and Herzegovina between 1992 and 1995 caused many people to leave their home and take refuge on the other side of the front line. Table 1 describes this homogenization of the two entities of Bosnia and Herzegovina. The share of Serbs in the Federation of Bosnia and Herzegovina shrank to $2.3 \%$ from $17.6 \%$, while the share of Bosniaks (Croats) went down to $2.2 \%$ from $28.1 \%$ (1\% from 9.2\%). Serbs were leaving from the Bosnian/Croatian side of the front line to the Serb side and Bosniaks/Croats the other way round.

During the war, Bosniaks and Croats in the Serb territory were at risk of being killed, what became to be known as "ethnic cleansing". A main goal of Serb forces was to create an ethnically homogeneous territory within Bosnia and Herzegovina. Serbs beyond the front line faced a similar fate and were abandoning whole villages within a few days (Silber and Little 1996, p.358). Even after the Dayton Agreement was signed, displacement did not come to a halt. Several villages in the Federation of Bosnia and Herzegovina and suburbs of Sarajevo are reported to have been abandoned after the local Serbs realized they were trapped in Bosniak territory (Silber and Little 1996, p.30). Thus displacement during and after the war produced for the most part ethnically homogeneous regions.

Of course displacement status is not a question in the LSMS and has to be inferred from the data. The data include the municipality of residence right before the war and the location of residence in 2001. When a person did not move at all, he/she enters the control groups of non-movers. If a person resided on the other side of the front line before the war than he/she does in 2001, the person is considered displaced. People who changed their location of residence but did not cross the front line or people who returned to their pre-war residence are dropped. A household enters either the control or treatment group when both, the household head and his/her spouse, did not move or got displaced.

Note that the identification strategy implies the ethnicity of a person. A person living in the current Republika Srpska before the war and is now living in Federation of Bosnia and Herzegovina, the person is considered to be a displaced Bosniak. Conversely, a person, who has moved from the Federation of Bosnia and Herzegovina before the war to

Table 1 Main ethnic groups in Bosnia and Herzegovina

\begin{tabular}{lccc}
\hline \multicolumn{2}{c}{$\begin{array}{c}\text { Bosnia and Herzegovina (Overall) } \\
\text { Bosniaks }\end{array}$} & Serbs & Croats \\
\hline 1991 & $43.5 \%$ & $31.2 \%$ & $17.4 \%$ \\
1996 & $46.1 \%$ & $37.9 \%$ & $14.6 \%$ \\
\multicolumn{2}{c}{ Federation of Bosnia and Herzegovina } & & \\
\multicolumn{2}{c}{ Bosniaks } & Serbs & Croats \\
\hline 1991 & $52.3 \%$ & $17.6 \%$ & $21.9 \%$ \\
1996 & $72.5 \%$ & $2.3 \%$ & $22.8 \%$
\end{tabular}

\begin{tabular}{lccc} 
Republika Srpska & & & \\
& Bosniaks & Serbs & Croats \\
\hline 1991 & $28.1 \%$ & $55.4 \%$ & $9.2 \%$ \\
1996 & $2.2 \%$ & $96.8 \%$ & $1.0 \%$ \\
\hline
\end{tabular}

Source: Official census in 1991 and unofficial census conducted by the UN in 1996. 
the Republika Srpska after the war, is considered to be a displaced Serb. However, information about the ethnicity of a person is not available in the first wave of the data set, but only in the smaller second wave. Hence, I can test this prediction of the ethnicity by the migration pattern only on this smaller sample. Table 2 reports the ethnicities of the groups of non-movers and displaced people. Out of 1,040 displaced individuals, there is one Croat and no Serb in the Federation of Bosnia and Herzegovina and one Bosniak and one Croat in the Republika Srpska. The ethnicity mix in the sample of non-movers is not as clear-cut, which probably originates in the presence of enclaves in both, the Republika Srpska and the Federation of Bosnia and Herzegovina. However, these enclaves do not pose a threat to my identification, because these people did not got "treated" by forced displacement, neither did they endogenously decide to migrate. The evidence in Table 2 is a strong argument in support of my identification strategy. ${ }^{5}$

The first main threat to the identifying assumptions would be a systematic course of the front line so that economically different areas were divided. If economically undeveloped areas were targeted and conquered during the war, the displaced households were poorer than their non-mover counterparts already before the war. Kondylis (2010, p.241f) discusses this possibility and concludes that the war was "determined more by geo-strategic motives rather than economic motives". The Serb invasion followed the goal to connect the Serb stronghold around Banja Luka with the Serb nation. In addition, Kondylis (2010) provides evidence that pre-war educational attainment is uncorrelated with war casualties (and hence developed areas were not more contested) and there is no clear connection between the pre-war ethnic mix and war intensity.

The second key assumption implies that, ex ante, displaced households were not different from non-mover households. One possibility is that households of a certain type could have moved into areas, where they were especially exposed to the risk of displacement. This includes, for instance, a Bosniak family moved to Banja Luka (now the capital of the Republika Srpska) before the war so the household head could take a good position there. The data does not suggest evidence of sorting before the war in Bosnia and Herzegovina, as $70 \%$ of the household heads in the data still lived in their municipality of birth just before the war. Considering the small size of the average municipality in Bosnia and Herzegovina of $373 \mathrm{~km}^{2}$, this suggests that households generally do not exhibit high mobility. Moreover, the results of the paper are not sensitive to restricting the sample to households who still resided in their birth municipality just before the war. If the results

Table 2 Displacement by ethnic groups

\begin{tabular}{llcc}
\hline & & \multicolumn{2}{c}{ After-war entity of residence } \\
\cline { 3 - 4 } & & $\begin{array}{c}\text { Federation of Bosnia } \\
\text { and Herzegovina }\end{array}$ & Republika Srpska \\
\hline Displaced & Bosniak & 285 & 1 \\
& Serb & 0 & 747 \\
& Croatian & 1 & 1 \\
Not moved & Other & 5 & 0 \\
& Bosniak & 2,847 & 59 \\
& Serb & 121 & 2,306 \\
& Croatian & 614 & 39 \\
\hline
\end{tabular}

Ethnicity data are from the second wave of the the LSMS on Bosnia and Herzegovina, which only includes half of the household from the first wave. The number of observations is reported. 
are purely driven by pre-war geographic sorting, the findings would vanish in such a selected sample.

Another potential problem is that households with certain characteristics were displaced, while others at the same location and of the same ethnicity did not move, and hence displacement was not a life-saving treatment as suggested earlier. In terms of observable characteristics displaced and non-mover households do not differ as the descriptive statistics in Table 3 show. While Serbs in the sample were more likely to be displaced, there is no significant difference in other household characteristics. There is also no difference in the distributions of the highest level of education achieved and the age of the household head using a Kolmogorov-Smirnov equality of distributions test. ${ }^{6}$ The column "Regression" reports the point estimate of a regression of the household characteristic on the displacement indicator and municipality fixed effects. However, regional differences are not a problem as municipality fixed effects are included in all regressions.

Table 4 tests whether the pre-war household characteristics are jointly correlated with displacement. In a regression of the displacement indicator on the characteristics, only the dummy variable for the Serb territory is a good predictor of displacement. The variables of household and child characteristics (the number of children of the family in school, a dummy variable for the oldest child of the family, a dummy for female children, years of education and age of the household head) are unable to significantly explain displacement. A joint test of the five household/child characteristics can not reject the hypothesis that displacement is a non-selective process. The results do not change when municipality fixed effects are included in column 2.

Even if household characteristics of displaced and non-movers are not significantly different from each other, pre-war experience could still affect education decisions. Although, each ethnicity has nominally their own language, there are only minor differences in the spoken word (Mappes-Niediek 2009, p.30). One might argue that the

Table 3 Descriptive statistics and exogeneity of displacement

\begin{tabular}{|c|c|c|c|c|c|}
\hline & All & Not moved & Displaced & Difference & Regression \\
\hline Displaced Family & 0.189 & 0 & 1 & & \\
\hline \multirow[t]{2}{*}{ Republika Srpska } & 0.44 & 0.40 & 0.61 & $0.21^{* * *}$ & \\
\hline & & & & $(0.037)$ & \\
\hline Number of Children & 1.81 & 1.81 & 1.81 & 0.00 & $0.09^{*}$ \\
\hline of Family in School & & & & $(0.056)$ & $(0.054)$ \\
\hline Oldest Child & 0.41 & 0.41 & 0.40 & -0.01 & -0.01 \\
\hline of Family & & & & $(0.023)$ & $(0.025)$ \\
\hline \multirow[t]{2}{*}{ Female Child } & 0.47 & 0.47 & 0.48 & 0.01 & 0.02 \\
\hline & & & & $(0.028)$ & $(0.030)$ \\
\hline Education of & 10.30 & 10.34 & 10.10 & -0.25 & -0.22 \\
\hline Household Head & & & & $(0.279)$ & $(0.305)$ \\
\hline Age of & 45.74 & 45.80 & 45.47 & -0.33 & -0.87 \\
\hline Household Head & & & & $(0.735)$ & $(0.834)$ \\
\hline Municipality FE & & & & & Yes \\
\hline Observations & 1,952 & 1,584 & 368 & 1,952 & 1,952 \\
\hline
\end{tabular}

Significance levels: ${ }^{*}: 10 \%{ }^{* *}: 5 \%{ }^{* *}: 1 \%$.

Standard errors clustered at the household level in parenthesis.

The column "Regression" reports the point estimate of a regression of the household characteristic on the displacement

indicator and municipality fixed effects. 
Table 4 Regression output: displacement

\begin{tabular}{lcc}
\hline & & Dep. variable: displaced family \\
\hline Republika Srpska & $0.136^{* * *}$ & \\
Number of Children & $(0.0239)$ & 0.021 \\
of Family in School & -0.000 & $(0.0148)$ \\
Oldest Child & $(0.0150)$ & -0.009 \\
of Family & -0.011 & $(0.0140)$ \\
Female Child & $(0.0154)$ & 0.011 \\
& 0.008 & $(0.0110)$ \\
Education of & $(0.0080)$ & -0.004 \\
Household Head & -0.004 & $(0.0036)$ \\
Age of & $(0.0038)$ & -0.002 \\
Household Head & $-0.002^{*}$ & $(0.0012)$ \\
\hline Municipality FE & $(0.0012)$ & Yes \\
\hline Observations & & 1,952 \\
R-squared & 1,952 & 0.162 \\
\hline F-value & 0.031 & 1.19 \\
(p-value) & 0.70 & $(0.310)$ \\
\hline
\end{tabular}

Significance levels: $*: 10 \% * *: 5 \% * * * 1 \%$

Standard errors clustered at the household level in parenthesis.

The F-value ( $p$-value) corresponds to a test of the joint hypothesis that the effects of the five control variables (not the geographic control for the Republika Srpska) are zero.

group of displaced were ethnic minorities before the war and were ousted by the majority population. This is true at the entity level, but in more narrowly defined regions the displaced were often the ethnic majority but had to flee nevertheless. As Mappes-Niediek (2009, p.44f) describes it is a myth that households were driven out by neighbors of different ethnicity, but mostly by militants form other parts of Yugoslavia or soldiers. Reports describe ethnically different neighbors to have been close friends and attempted to protect each other from attacks. Since the three different ethnic groups have lived together in Bosnia and Herzegovina for a long time (the geographic distribution of ethnic groups in 1910 is very similar to the one in 1991) and the lack of major conflicts between those groups indicates that no group was suppressed by another one. Hence, there is limited reason to suspect a systematic pre-war difference of the later displaced population to the non-movers. Put differently, the pattern of displacement in a certain municipality was arguably driven by the geopolitical situation and not by the characteristics of a certain group in that municipality.

A final concern to identification is international migration/displacement. The Ministry for Human Rights and Refugees (MHHR 2003) reports the number of international refugees as 1.2 million between 1992 and the end of the war, which is more than a quarter of the total population in Bosnia and Herzegovina before the war. About half of this group returned to their home country until 2003. This is potentially a threat to the identification strategy if the families who left Bosnia and Herzegovina during the war have a characteristic that is different to the people who stayed in the country and if the treatment and control groups are unequally affected.

For this purpose I compare the displaced Serbs in Bosnia and Herzegovina to the residents of the Republic of Serbia who lived in Bosnia and Herzegovina in 1991 using the LSMS of Serbia in 2002. Serbs living in the future Federation of Bosnia and Herzegovina 
(the Bosniak territory) before the war had the choice between internal displacement and displacement/migration to the Republic of Serbia. I find that household heads and their spouses in the Republic of Serbia have on average 1.4 years more of education and are 4 years younger (results not shown).

These numbers suggest that the internally displaced are different from the externally displaced, which confirms the finding of Kondylis (2010) for migration to Western European countries. However, the fact that within Bosnia and Herzegovina the displaced and the non-movers are indistinguishable in terms of education and age (Table 3) indicates that my treatment and control groups were equally affected by internal displacement/migration and international displacement/migration is therefore not a problem for identification. Anyways, the problem of international migration/displacement is common in the literature on conflicts, because micro data set usually restrict the sample to a country.

\section{Main results}

The treatment effect of displacement on education expenditure is estimated by Ordinary Least Squares (OLS) of the estimating equation

$$
y_{i, j}=\delta d_{i, j}+X_{i, j} \beta+\eta_{j}+\varepsilon_{i, j}
$$

where $y_{i, j}$ is the log. of education expenditure on child $i$ in municipality $j, d_{i, j}$ is the displacement indicator, $X_{i, j}$ are exogenous control variables (ie. exogenous in the sense that they are not influenced by displacement as well as uncorrelated with the error term), $\eta_{j}$ is a municipality fixed effect, and $\varepsilon_{i, j}$ is an error term. The standard errors are clustered at the household level to account for intra-household correlation of the error term.

The selection issues discussed in the previous sections would be a problem if $d_{i, j}$ and $\varepsilon_{i, j}$ are correlated. However, the discussion showed that many issues can be ruled out. I also employ nearest neighbor-matching as an alternative estimation method to check the robustness of the OLS findings.

\subsection{Preliminary evidence}

In a first step, I plot the Kernel density function of education expenditure of displaced and non-mover households against each other. Panel (a) in Figure 1 shows the unconditional densities while Panel (b) depicts deviations from municipality means. It is clearly visible that the whole distribution of the displaced households is shifted to the left of the distribution of the non-mover households, both, unconditionally and in deviations from municipality means.

Table 5 reports descriptive statistics for the various expenditure groups per child in Convertible Mark, the local currency. In a regression of the expenditure category on the displacement indicator and municipality fixed effects, only few categories show a significant difference. A simple difference of means between non-movers and displaced households would not be informative due to regional variation in education expenditure, therefore the regression.

Education expenditure is not a trivial part of total expenditure for households in Bosnia and Herzegovina. The average annual expenditure on education per child is 267.1 Convertible Mark, while the average total household income per month in the data set is 481 Convertible Mark. On average $4.6 \%$ of the annual total household income is spent on the 


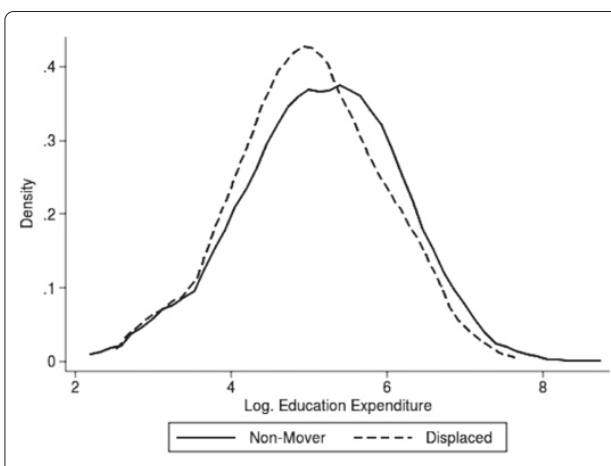

(a) Unconditional difference

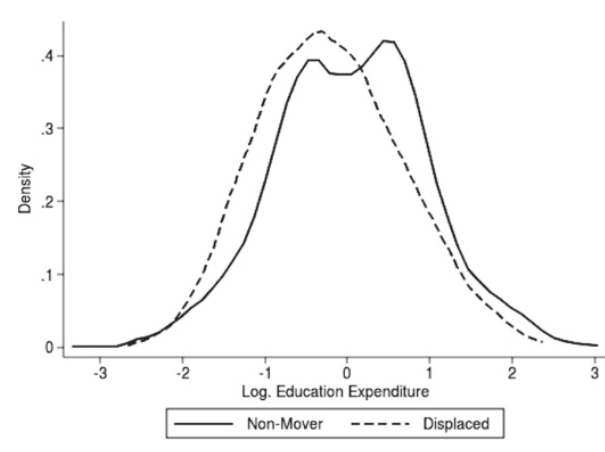

(b) Within-municipality difference

Figure 1 Difference in education expenditure of displaced vs. non-mover households. Panel (a) shows the unconditional difference, while Panel (b) displays within-municipality differences.

education of a child. This a high price to pay for generally "free" education, which causes Mooney and French (2005) to suggest financial support for the education of children of displaced households.

In most specifications I use the sum of all expenditure classes, because of the group called "Total cost (not included in previous classes)". This expenditure class forms a pool for expenses, that parents cannot classify or do not bother to split up into the exact

Table 5 Descriptive statistics: education expenditure by classes

\begin{tabular}{lccc}
\hline & Mean & Standard deviation & Regression \\
\hline Annual Tuition & 12.1 & $(58.9)$ & -3.6 \\
Special Tuition & 2.1 & $(25.2)$ & $(2.39)$ \\
Membership Fee for & 0.7 & $(16.5)$ & $(1.99)$ \\
Parent's Association & & & -0.1 \\
School Uniforms and & 36.5 & $(89.4)$ & $(0.22)$ \\
Other School Clothing & & & -7.7 \\
Textbooks & 35.3 & $(53.6)$ & $(4.98)$ \\
Other School Materials & 31.5 & & -2.5 \\
Food and Lodging & & $(34.5)$ & $(4.51)$ \\
& 44.2 & $(104.0)$ & -2.4 \\
Other Costs & & & $(2.55)$ \\
& 19.9 & $(71.9)$ & $-16.3^{* * *}$ \\
Total Costs (not included & & & $(5.7)$ \\
in previous classes) & & $(275.5)$ & $-13.6^{* * *}$ \\
Expenditure on Education & & & $(4.27)$ \\
(sum of all groups) & & & $-28.8^{* *}$ \\
\hline Municipality FE & & $(316.4)$ & $(14.62)$ \\
\hline Observations & & & $-73.4^{* * *}$ \\
\hline Signicanc & & & $(17.18)$ \\
\hline
\end{tabular}

Significance levels: ${ }^{*}: 10 \% * *: 5 \% * * * 1 \%$.

Standard errors clustered at the household level in parenthesis.

Values are denoted in Convertible Mark. The column "Regression" reports the coefficient of a regression of the expenditure category on the displacement indicator and municipality fixed effects. A direct comparison of means between non-movers and displaced households is not informative due to regional variation in education expenditure. 
groups. The problem is that the group "Total cost (not included in previous classes)" is negatively correlated with all other groups, which suggests that some households do not take the effort to split up the expenditures into the various classes and put everything into this group. Since dropping such households would reduce the sample size considerably, I use the sum of all groups in the main specifications to avoid the loss of many observations. In additional specifications, I restrict myself to a number of selected groups and drop the households that use the class "Total cost (not included in previous classes)".

\subsection{Total causal effect}

In this section, I present the estimation results for the total causal effect of displacement on education expenditure. The robustness checks show that the difference in spending on education holds across various specifications. An exact interpretation of dummy variables in semi-logarithmic regressions is provided in the row "Transformation" following van Garderen and Shah (2002). However, the exact interpretation deviates from the regression coefficients only slightly and also statistical significance remains unchanged.

The main results are reported in Table 6: the findings indicate a highly significant and robust drop in education expenditure in all specifications. Quantitatively, the difference in education expenditure between displaced parents and parents that did not move during the war is in the ballpark of 25 to $30 \%$ depending on the specification. Column (1) reports the difference controlling only for the entity of residence. Including control variables for child and parent characteristics (column (2)) hardly changes the estimated effect. The inclusion of municipality fixed effects increases the effect to a difference of almost $30 \%$, which is identical between the two entities as column (4) shows.

Column (5) tests whether displaced parents discriminate between boys and girls, but shows that there is no significant difference. In column (6) I interact the displacement variable with the secondary school variable to test whether the difference in education expenditure originates in primary or secondary school. The point estimate of the interaction term is zero and hence displaced parents spend less in both, primary and secondary school.

In column (7), I control for the grade of school the child is in. This variable might be influenced by displacement, as children of displaced parents might only attend lower grades and therefore education might be cheaper. Then the difference in education expenditure would not be a decision of the parents, but imposed by the system. However, when the grade of the school is included in the regression, the point estimate increases to a difference of almost $33 \%$.

In Table 7, I estimate the effect of displacement using a nearest-neighbor matching estimator. This method pairs individuals of ex ante comparable observable characteristics who differ only by treatment status and calculates the difference in the outcome variable (matching by covariates). The matching estimator may improve upon simple regression by comparing only individuals with similar observable characteristics and by doing so hopes to also balance unobservable characteristics. Hence, matching can reduce a potential bias of the estimated treatment effect due to selection issues if the distribution of observable characteristics contains information on the distribution of unobservable characteristics.

The average treatment effect in column (1) is a difference in education expenditure of $33 \%$, while the average treatment effect on the treated in column (2) is $44 \%$. These 
Table 6 Regression output: education expenditure I

\begin{tabular}{|c|c|c|c|c|c|c|c|}
\hline & \multicolumn{7}{|c|}{ Log. of education expenditure } \\
\hline & (1) & (2) & (3) & (4) & (5) & (6) & (7) \\
\hline \multirow[t]{2}{*}{ Displaced Family } & $-0.250^{* * *}$ & $-0.240^{* * *}$ & $-0.294^{* * *}$ & $-0.299^{* *}$ & $-0.346^{* * *}$ & $-0.299 * * *$ & $-0.329 * * *$ \\
\hline & $(0.0699)$ & $(0.0697)$ & $(0.0670)$ & $(0.1187)$ & $(0.0763)$ & $(0.0722)$ & $(0.0663)$ \\
\hline \multirow[t]{2}{*}{ Displaced Family × Republika Srpska } & & & & 0.009 & & & \\
\hline & & & & $(0.1434)$ & & & \\
\hline \multirow[t]{2}{*}{ Displaced Family $\times$ Female Child } & & & & & 0.111 & & \\
\hline & & & & & $(0.0977)$ & & \\
\hline \multirow[t]{2}{*}{ Displaced Family $\times$ Secondary School } & & & & & & 0.000 & \\
\hline & & & & & & $(0.1197)$ & \\
\hline \multirow[t]{2}{*}{ Secondary School } & & & & & & $0.285^{* * *}$ & \\
\hline & & & & & & $(0.0558)$ & \\
\hline \multirow[t]{2}{*}{ Grade of School } & & & & & & & $0.074^{* * *}$ \\
\hline & & & & & & & $(0.0074)$ \\
\hline \multirow[t]{2}{*}{ Republika Srpska } & $0.461^{* * *}$ & $0.455^{* * *}$ & & & & & \\
\hline & $(0.0536)$ & $(0.0540)$ & & & & & \\
\hline \multirow[t]{2}{*}{ Number in Children of Family in School } & & $0.083^{*}$ & 0.030 & 0.030 & 0.030 & 0.021 & -0.003 \\
\hline & & $(0.0430)$ & $(0.0347)$ & $(0.0347)$ & $(0.0346)$ & $(0.0345)$ & $(0.0344)$ \\
\hline \multirow[t]{2}{*}{ Oldest Child of Family } & & $0.236^{* * *}$ & $0.246^{* * *}$ & $0.245^{* * *}$ & $0.244^{* * *}$ & $0.205^{* * *}$ & $0.153^{* * *}$ \\
\hline & & $(0.0430)$ & $(0.0394)$ & $(0.0394)$ & $(0.0394)$ & $(0.0402)$ & $(0.0407)$ \\
\hline \multirow[t]{2}{*}{ Female Child } & & 0.058 & 0.064 & 0.064 & 0.043 & $0.069^{*}$ & 0.065 \\
\hline & & $(0.0444)$ & $(0.0412)$ & $(0.0412)$ & $(0.0470)$ & $(0.0410)$ & $(0.0402)$ \\
\hline \multirow[t]{2}{*}{ Education of Household Head } & & $0.014^{*}$ & $0.021^{* * *}$ & $0.021^{* * *}$ & $0.021^{* * *}$ & $0.018^{* *}$ & $0.016^{* *}$ \\
\hline & & $(0.0084)$ & $(0.0079)$ & $(0.0080)$ & $(0.0079)$ & $(0.0079)$ & $(0.0077)$ \\
\hline \multirow[t]{2}{*}{ Age of Household Head } & & $0.008^{* * *}$ & $0.010^{* * *}$ & $0.010^{* * *}$ & $0.010^{* * *}$ & $0.007^{* * *}$ & 0.004 \\
\hline & & $(0.0029)$ & $(0.0027)$ & $(0.0027)$ & $(0.0027)$ & $(0.0027)$ & $(0.0027)$ \\
\hline \multirow[t]{2}{*}{ Transformation } & $-22.29 * * *$ & $-21.56^{* * *}$ & $-25.64^{* * *}$ & $-26.39 * * *$ & $-29.47^{* * *}$ & $-26.03^{* * *}$ & $-28.21^{* * *}$ \\
\hline & $(5.423)$ & $(5.458)$ & $(4.974)$ & $(8.705)$ & $(5.376)$ & $(5.334)$ & $(4.753)$ \\
\hline Municipality FE & & & Yes & Yes & Yes & Yes & Yes \\
\hline No. Observations & 1,952 & 1,952 & 1,952 & 1,952 & 1,952 & 1,952 & 1,952 \\
\hline R-squared & 0.054 & 0.071 & 0.201 & 0.201 & 0.202 & 0.215 & 0.244 \\
\hline
\end{tabular}

Significance levels: ${ }^{*}: 10 \%{ }^{* *}: 5 \%{ }^{* * *}: 1 \%$.

Standard errors clustered at the household level in parenthesis.

The line "Transformation" reports approximate unbiased estimator of the percentage change of a dummy variable in a semi-logarithmic regression (Kennedy 1981) and its standard error following van Garderen and Shah (2002).

numbers confirm the OLS results and are actually larger than those. The results are robust to an increase in the number of neighbors the treated observations are matched to. Column (3) includes only an indicator for the Republika Srpska and finds a difference of $22 \%$, which is comparable to the OLS estimate. The inclusion of regional control variables actually pose a violation of the assumptions of matching where the matching variables must be unaffected by the treatment. However, displacement affects the location of residence by definition. Column (4) tests the case without regional control variables and finds a similarly significant result. Hence, if matching is better able to deal with selection into treatment than OLS and it produces similar results, selection does not seem to drive the main findings of Table 6 .

A closer look at some education expenditure groups is taken in Table 8. For this table, I restrict the sample to the 1,325 children, whose parents split up all their costs to the detailed expenditure groups and did not use the category "Total Costs (not included in 
Table 7 Regression output: nearest-neighbor matching

\begin{tabular}{|c|c|c|c|c|}
\hline & \multicolumn{4}{|c|}{ Log. of education expenditure } \\
\hline & (1) & (2) & (3) & (4) \\
\hline \multirow[t]{2}{*}{ Displaced Family } & $-0.330^{* * *}$ & $-0.440^{* * *}$ & $-0.222^{* * *}$ & $-0.205^{* * *}$ \\
\hline & $(0.0822)$ & $(0.0772)$ & $(0.0701)$ & $(0.0653)$ \\
\hline Average Treatment Effect & Yes & & Yes & Yes \\
\hline Average Treatment Effect on the Treated & & Yes & & \\
\hline Municipality FE & Yes & Yes & & \\
\hline Control for Republika Srpska & & & Yes & \\
\hline No. Observations & 1,952 & 1,952 & 1,952 & 1,952 \\
\hline
\end{tabular}

previous classes)". Including a child with zero reported expenditure on textbooks, for instance, and a single position in the group of unclassified expenditures would lead to unreasonable results in these regressions.

In primary school (grades 1-8) only few parents pay annual tuition and as column (1) shows, there is no significant difference in spending. However, in secondary school, where areas of specialization are offered, there is a large and significant difference between children of displaced and non-mover parents. Regression (2) shows a reduction by about $80 \%$. In terms of other school material, which includes notebooks, pencils, etc., there is a difference of $17.1 \%$. The spending on textbooks in column (4) is conditional on positive spending on textbooks by anyone in the municipality, because in some municipalities textbooks are provided by the municipality or the federal government. The difference is still a significant $21.4 \%$. Adding up these three groups, which seem to be especially important for the quality of education, I estimate a difference of $14.6 \%$.

These results suggest that displaced parents restrict expenditures on the education of their children wherever they can, that is even in matters like the choice of the secondary school and the provision of study materials.

Table 8 Regression output: education expenditure II

\begin{tabular}{|c|c|c|c|c|c|}
\hline & $\begin{array}{l}\text { Annual } \\
\text { tuition }\end{array}$ & $\begin{array}{l}\text { Annual } \\
\text { tuition }\end{array}$ & $\begin{array}{l}\text { Other school } \\
\text { materials }\end{array}$ & Textbooks & $\begin{array}{c}\text { Important } \\
\text { groups }\end{array}$ \\
\hline & (1) & $(2)$ & (3) & (4) & (5) \\
\hline \multirow[t]{2}{*}{ Displaced Family } & 0.148 & $-0.805^{* * *}$ & $-0.171^{* *}$ & $-0.214^{* *}$ & $-0.146^{* *}$ \\
\hline & $(0.1371)$ & $(0.2937)$ & $(0.0759)$ & $(0.0910)$ & $(0.0617)$ \\
\hline Primary School Only & Yes & & & & \\
\hline Secondary School Only & & Yes & & & \\
\hline Controls & Yes & Yes & Yes & Yes & Yes \\
\hline Municipality FE & Yes & Yes & Yes & Yes & Yes \\
\hline No. Observations & 984 & 341 & 1,325 & 1,101 & 1,325 \\
\hline R-squared & 0.078 & 0.278 & 0.164 & 0.724 & 0.428 \\
\hline
\end{tabular}

Standard errors clustered at the household level in parenthesis.

Significance levels: ${ }^{*}: 10 \%{ }^{* *}: 5 \%{ }^{* * *}: 1 \%$.

Control variables include number of children in $\mathrm{HH}$ enrolled in school, education of $\mathrm{HHH}$, age of $\mathrm{HHH}$ and dummy variables for being the oldest child and females. Only households with zero expenditure in the residual category "Total Costs (not included in previous columns)" are used in all regressions. In the regression "Textbooks", only municipalities with some positive expenditures were used. "Important Groups" is the sum of the previous three groups. All independent variables are in measured in logs. 
The specifications in Table 9 perform some robustness checks. If someone outside the household paid for education expenditures and that is the reason why parents spend less, the difference in education expenditure could be inconsequential for educational output. Das et al. (2013) show that anticipated public supply of additional school inputs in India and Zambia is offset by an expenditure reduction of parents. Fortunately, the LSMS records the expenses paid from someone outside the household, however only as the total amount. Including these expenditures and running the baseline regressions with the new dependent variable in column (1) reduces the difference in education expenditure to $23.8 \%$ but remains highly significant. Restricting the sample to the households without any outside funds for education in column (2) shows a slightly increased difference of $30.6 \%$. These findings imply that the reduced education expenditure is not driven by displaced households who are substituting for additional external funds.

In column (3) dummy variables for rural and mixed municipalities are interacted with the displacement dummy, while the base group are urban municipalities. The interaction terms produce positive, but insignificant point estimates, while the difference in the base group is estimated at $37 \%$. When the sample is restricted to households that still lived in their municipality of birth just before the war, one can rule out that some households self-selected to a higher risk of displacement through migration before the war and now drive the main finding. This can be ruled out as the restricted sample, that did not migrate before the war, also spends $29.1 \%$ less on the education of their children.

To sum up, I find a strong negative relationship between displacement and the spending on the education of their children. The result is robust to a number of sample restrictions and the inclusion of various control variables.

\section{Table 9 Regression output: education expenditure III}

\begin{tabular}{lcccc}
\hline & \multicolumn{3}{c}{ Log. of education expenditure } \\
\cline { 2 - 5 } & $\begin{array}{c}\text { All funds } \\
\mathbf{( 1 )}\end{array}$ & $\begin{array}{c}\text { Original } \\
\mathbf{( 2 )}\end{array}$ & $\begin{array}{c}\text { Original } \\
\mathbf{( 3 )}\end{array}$ & $\begin{array}{c}\text { Original } \\
\mathbf{( 4 )}\end{array}$ \\
\hline Displaced Family & $-0.238^{* * *}$ & $-0.306^{* * *}$ & $-0.370^{* * *}$ & $-0.291^{* * *}$ \\
& $(0.0723)$ & $(0.0721)$ & $(0.0971)$ & $(0.0830)$ \\
Displaced Family $\times$ & & & 0.151 & \\
Rural Municipality & & & $(0.1646)$ & \\
Displaced Family $\times$ & & 0.183 & \\
Mixed Municipality & & & & \\
\hline No Funds from Outside of Household & & & & Yes \\
Never Moved before War & Yes & Yes & Yes & Yes \\
\hline Controls & Yes & Yes & Yes & Yes \\
Municipality FE & 1,947 & 1,827 & 1,952 & 1,454 \\
\hline No. Observations & 0.170 & 0.202 & 0.202 & 0.184 \\
R-squared & & & & \\
\hline Standard & & & & \\
\hline
\end{tabular}

Standard errors clustered at the household level in parenthesis.

Significance levels: ${ }^{*}: 10 \%^{* *}: 5 \%{ }^{* * *}: 1 \%$.

Control variables include number of children in $\mathrm{HH}$ enrolled in school, education of $\mathrm{HHH}$, age of $\mathrm{HHH}$ and dummy variables

for being the oldest child and females. "All Funds" includes education expenditures paid by someone from outside the

household. Column (2) restricts the sample to households that do not receive funds for education from outside the

household. Column (4) restricts the sample to households who still lived in their municipality of birth before the war. 


\section{Channels}

So far the paper focused on estimating the total causal effect of displacement on education expenditure, but has not offered a channel through which this effect might work. However, it is of great interest to researchers and policy makers alike to understand the mechanisms through which displacement operates. I first start with some econometric considerations to guide the analysis.

\subsection{Econometric considerations}

The estimation of the channel through which displacement works faces two issues: First, including a variable of a channel introduces an endogenous variable and hence OLS produces biased estimates. And second, the proper counterfactual of an evaluation of a channel changes the interpretation of the estimation results.

\subsubsection{Evaluating the indirect effect}

The following two equations describe the effect of displacement through an intermediary variable $m_{i}$ (eg. income) on education expenditure. Municipality fixed effects are omitted for simplicity.

$$
\begin{aligned}
y_{i} & =\delta_{1} d_{i}+X_{i} \beta_{1}+\rho_{1} m_{i}+\theta_{1} m_{i} d_{i}+\varepsilon_{1 i} \\
m_{i} & =\delta_{2} d_{i}+X_{i} \beta_{2}+\varepsilon_{2 i}
\end{aligned}
$$

In these equations, displacement has a direct effect $\delta_{1}$ on education expenditure, changes the intermediary variable through $\delta_{2}$, and might influence the effect of the intermediary variable on education expenditure through $\theta_{1}$. Simply including the intermediary variable and its interaction with displacement introduces an endogeneity problem as $\operatorname{Cov}\left(\varepsilon_{1 i}, \varepsilon_{2 i}\right)$ might be nonzero. In the case of $\operatorname{Cov}\left(\varepsilon_{1 i}, \varepsilon_{2 i}\right) \neq 0$, the OLS estimates in equation (2) will be biased (Angrist and Pischke 2009, p.64). However, the bias can be signed: Using income as an example, it is most likely that $\operatorname{Cov}\left(\varepsilon_{1 i}, \varepsilon_{2 i}\right)>0$, as high income households are more likely to value education more. This causes the estimate of $\rho_{1}$ to be biased upwards, ie. the indirect channel of displacement-on-income-on-education expenditure captures too much of the total effect and hence results in a downward bias of $\delta_{1}$.

\subsubsection{Counterfactual}

The second problem in these regressions concerns the proper counterfactual. The question I want to answer with these regressions is: "Would the household spend less on education even if displacement would not have changed the intermediary variable?" In a usual regression of education expenditure on a displacement indicator, the intermediary variable, and its interaction with displacement, one has to do some calculations to get a precise answer to the question above and hypothesis testing gets more difficult. However, when the intermediary variable is redefined a single parameter delivers a sufficient answer.

The conditional expectation function is (control variables $X_{i}$ omitted)

$$
E\left[y_{i} \mid d_{i}, m_{i}\right]=\alpha+\delta d_{i}+\rho m_{i}+\theta m_{i} d_{i}
$$


Redefine the intermediary variable by subtracting the average of the intermediary variable of the non-displaced households:

$$
\tilde{m}_{i}=m_{i}-E\left[m_{i} \mid d_{i}=0\right]
$$

Then the expected difference in education expenditure between displaced and nonmovers, given no change of the intermediary variable by displacement is

$$
\begin{aligned}
E\left[y_{i} \mid d_{i}=1, \tilde{m}_{i}=E\left[\tilde{m}_{i} \mid d_{i}=0\right]\right]-E\left[y_{i} \mid d_{i}=0\right] & =\delta+(\rho+\theta) \tilde{m}_{i}-\rho \tilde{m}_{i} \\
& =\delta
\end{aligned}
$$

since $E\left[\tilde{m}_{i} \mid d_{i}=0\right]=0$.

Therefore the transformation of the intermediary variable allows me to estimate the difference in education expenditure under the assumption of no change of the intermediary variable through displacement with the single parameter $\delta$. All other estimators remain unchanged because variances and covariances do not change by subtracting a constant.

\subsection{Income, the stock of durable goods, and the housing situation}

One of the most natural explanations for the difference in education expenditure is that displaced families have lower income and wealth. It is not surprising that displaced households have lower labor income and wealth, especially real estate, than households that did not have to move during the war. When households get displaced, they usually do not have time to sell their real estate, which is often the most valuable asset of a family. If displaced families rent a dwelling while the non-mover families have inherited a house to live in, it would not be surprising that displaced households spend less on education of their children.

The descriptive statistics in Table 10 document that displaced households experience a significant reduction in income, the stock of durable goods, and are less likely to own the dwelling they live in. Total income is lower for displaced households, but higher nonlabor income (pensions and allowances) partly counterbalance the reduction in labor income. Also the share reporting zero labor income of $36.1 \%$ is a lot higher than that of non-movers of $19.1 \%$. A large difference is in the stock of durable goods, which can be considered as a proxy for wealth as data on financial assets is not available.

The last three rows show the limited information on the housing situation available. The share of families that own the dwelling they live in is almost eight times as high for the non-movers than it is for the displaced. Displaced families mostly rent the place they live in, but a share of almost $16 \%$ live in a place without paying for it (either on loan from friends or families, as illegal occupants in abandoned houses, or in emergency lodges). These differences are prime candidates to explain the large reduction in education expenditure found earlier.

Income and wealth is controlled for with several different variables. Household labor income measures the sum of labor income reported for the last month by household members. Household non-labor income measures the sum of pensions and allowances per month received by household members, while total household income is composed of the sum of the two aforementioned variables. The variable durables is the sum of the values of reported durable goods in the household, but not financial assets or real estate. Dummy variables for a reported value of zero for any of those variables are included in the regressions to allow for more flexibility. The housing situation is coded in three indicator 
Table 10 Descriptive statistics: income, durable goods, and housing

\begin{tabular}{|c|c|c|c|c|}
\hline & All & Not moved & Displaced & Difference \\
\hline \multirow[t]{2}{*}{ Total HH Income } & 481 & 492 & 437 & $-54^{* *}$ \\
\hline & & & & (27.3) \\
\hline \multirow{2}{*}{$\begin{array}{l}\text { Total HH Income } \\
\text { (conditional on > 0) }\end{array}$} & 527 & 539 & 473 & $-66^{* *}$ \\
\hline & & & & $(28.2)$ \\
\hline \multirow{2}{*}{$\begin{array}{l}\text { Share with Zero Total } \\
\text { HH Income }\end{array}$} & 0.086 & 0.088 & 0.075 & -0.013 \\
\hline & & & & $(0.016)$ \\
\hline \multirow[t]{2}{*}{ HH Labor Income } & 404 & 426 & 313 & $-113^{* * *}$ \\
\hline & & & & (27.4) \\
\hline \multirow{2}{*}{$\begin{array}{l}\text { HH Labor Income } \\
\text { (conditional on > 0) }\end{array}$} & 521 & 527 & 490 & -37 \\
\hline & & & & (33.9) \\
\hline Share with Zero & 0.224 & 0.191 & 0.361 & $0.170^{* * *}$ \\
\hline \multicolumn{2}{|l|}{ HH Labor Income } & & & $(0.024)$ \\
\hline \multirow[t]{2}{*}{ HH Non-Labor Income } & 77 & 66 & 124 & $58^{* * *}$ \\
\hline & & & & $(8.9)$ \\
\hline \multirow{2}{*}{$\begin{array}{l}\text { HH Non-Labor Income } \\
\text { (conditional on > 0) }\end{array}$} & 188 & 174 & 229 & $55^{* * *}$ \\
\hline & & & & $(15.7)$ \\
\hline \multirow{2}{*}{$\begin{array}{l}\text { Share with Zero } \\
\text { HH Non-Labor Income }\end{array}$} & 0.590 & 0.621 & 0.458 & $-0.163^{* * *}$ \\
\hline & & & & $(0.29)$ \\
\hline \multirow[t]{2}{*}{ Stock of Durable Goods } & 2,688 & 2,884 & 1,852 & $-1,032^{* * *}$ \\
\hline & & & & $(244.7)$ \\
\hline \multirow{2}{*}{$\begin{array}{l}\text { Stock of Durable Goods } \\
\text { (conditional on }>0 \text { ) }\end{array}$} & 2,795 & 3,002 & 1,915 & $-1,087^{* * *}$ \\
\hline & & & & (251.8) \\
\hline \multirow{2}{*}{$\begin{array}{l}\text { Share with Zero } \\
\text { Stock of Durable Goods }\end{array}$} & 0.038 & 0.040 & 0.033 & -0.006 \\
\hline & & & & $(0.011)$ \\
\hline Housing Situation: & 0.655 & 0.790 & 0.108 & $-0.682^{* * *}$ \\
\hline \multicolumn{2}{|l|}{ Own Dwelling } & & & $(0.023)$ \\
\hline Housing Situation: & 0.264 & 0.148 & 0.733 & $0.585^{* * *}$ \\
\hline \multicolumn{2}{|l|}{ Rent Dwelling } & & & $(0.022)$ \\
\hline Housing Situation: & 0.081 & 0.062 & 0.159 & $0.097^{* * *}$ \\
\hline \multicolumn{2}{|l|}{ Live for Free } & & & $(0.016)$ \\
\hline Observations & 1,901 & 1,541 & 360 & \\
\hline
\end{tabular}

Standard errors in parenthesis.

Significance levels: ${ }^{*}: 10 \%{ }^{* *}: 5 \%{ }^{* * *}: 1 \%$.

Income is relates to monthly income. All income and wealth values are in Convertible Mark.

variables for ownership of dwelling, renting a dwelling, or living in the dwelling without paying for it.

The results of the regressions are shown in Table 11. Remember that the point estimates of the first row estimate the difference to the counterfactual of no reduction of income and/or durables. Also the unexplained part of the displacement effect is a lower bound as discussed above. However, the difference in education expenditure is surprisingly robust to the inclusion of income and durable goods variables. The difference decreases only slightly and rules out income and wealth differences as the main mechanism. Similarly the indicator variables for the housing situation fail to explain the difference in education expenditure.

The dummy variable for displacement remains significant at the one-percent level in most specifications and at the five-percent level in the regressions with the housing variables. The most flexible specification with income and durable goods variables in column 
Table 11 Regression output: income, durable goods, and housing

\begin{tabular}{|c|c|c|c|c|c|c|c|}
\hline & \multicolumn{7}{|c|}{ Log. of education expenditure } \\
\hline & (1) & (2) & (3) & (4) & (5) & (6) & (7) \\
\hline \multirow[t]{2}{*}{ Displaced Family } & $-0.293^{* * *}$ & $-0.233^{* * *}$ & $-0.254^{* * *}$ & $-0.257^{* * *}$ & $-0.209^{* * *}$ & $-0.316^{* *}$ & $-0.329^{* *}$ \\
\hline & $(0.0676)$ & $(0.0701)$ & $(0.0683)$ & $(0.0669)$ & $(0.0686)$ & $(0.1407)$ & $(0.1384)$ \\
\hline \multirow[t]{2}{*}{ Log. HH Total Income ${ }^{1}$} & $0.074^{*}$ & & & 0.051 & & & \\
\hline & $(0.0401)$ & & & $(0.0422)$ & & & \\
\hline Displaced Family $\times$ & 0.035 & & & 0.029 & & & \\
\hline Log. HH Total Income ${ }^{1}$ & $(0.0788)$ & & & $(0.0799)$ & & & \\
\hline \multirow[t]{2}{*}{ Log. HH Labor Income ${ }^{1}$} & & 0.042 & & & 0.009 & & 0.001 \\
\hline & & $(0.0516)$ & & & $(0.0555)$ & & $(0.0583)$ \\
\hline Displaced Family $x$ & & 0.076 & & & 0.072 & & 0.094 \\
\hline Log. HH Labor Income ${ }^{1}$ & & $(0.1062)$ & & & $(0.1128)$ & & $(0.1142)$ \\
\hline \multirow[t]{2}{*}{ Log. HH Non-Labor Inc. ${ }^{1}$} & & 0.026 & & & 0.023 & & 0.015 \\
\hline & & $(0.0423)$ & & & $(0.0422)$ & & $(0.0448)$ \\
\hline Displaced Family $\times$ & & 0.006 & & & -0.001 & & 0.006 \\
\hline Log. HH Non-Labor Inc. ${ }^{1}$ & & $(0.0800)$ & & & $(0.0799)$ & & $(0.0806)$ \\
\hline \multirow[t]{2}{*}{ Log. Durable Goods ${ }^{1}$} & & & $0.065^{* *}$ & $0.052^{*}$ & $0.060^{* *}$ & & $0.052^{*}$ \\
\hline & & & $(0.0266)$ & $(0.0283)$ & $(0.0289)$ & & $(0.0306)$ \\
\hline Displaced Family $\times$ & & & 0.055 & 0.046 & 0.015 & & 0.034 \\
\hline Log. Durable Goods ${ }^{1}$ & & & $(0.0559)$ & $(0.0568)$ & $(0.0589)$ & & $(0.0604)$ \\
\hline \multirow[t]{2}{*}{ Own Dwelling ${ }^{1}$} & & & & & & 0.161 & 0.160 \\
\hline & & & & & & $(0.1453)$ & $(0.1502)$ \\
\hline Displaced Family $\times$ & & & & & & 0.096 & -0.200 \\
\hline Own Dwelling ${ }^{1}$ & & & & & & $(0.2789)$ & $(0.2820)$ \\
\hline \multirow[t]{2}{*}{ Rent Dwelling ${ }^{1}$} & & & & & & 0.207 & 0.233 \\
\hline & & & & & & $(0.1558)$ & $(0.1607)$ \\
\hline Displaced Family $\times$ & & & & & & 0.093 & -0.073 \\
\hline Rent Dwelling ${ }^{1}$ & & & & & & $(0.2361)$ & $(0.2398)$ \\
\hline Zero Indicator ${ }^{1}$ & Yes & Yes & Yes & Yes & Yes & & Yes \\
\hline $\begin{array}{l}\text { Displaced Family } \times \\
\text { Zero Indicator }^{1}\end{array}$ & Yes & Yes & Yes & Yes & Yes & & Yes \\
\hline F-test & $7.51^{* * *}$ & $4.37^{* * *}$ & $5.92^{* * *}$ & $4.18^{* * *}$ & $2.99^{* * *}$ & $5.61^{* * *}$ & $2.12^{* *}$ \\
\hline Controls & Yes & Yes & Yes & Yes & Yes & Yes & Yes \\
\hline Municipality FE & Yes & Yes & Yes & Yes & Yes & Yes & Yes \\
\hline No. Observations & 1,901 & 1,901 & 1,901 & 1,901 & 1,901 & 1,783 & 1,783 \\
\hline R-squared & 0.250 & 0.253 & 0.251 & 0.255 & 0.258 & 0.216 & 0.231 \\
\hline
\end{tabular}

Standard errors clustered at the household level in parenthesis.

Significance levels: ${ }^{*}: 10 \% * *$ : $5 \% * * *: 1 \%$.

Control variables include number of children in $\mathrm{HH}$ enrolled, education of $\mathrm{HHH}$, age of $\mathrm{HHH}$ and dummy variables for being the oldest child and females. "F-test" results from a test of joint significance of displacement and all its interactions.

${ }^{1}$ Measured as the difference to the mean of non-movers.

(5) shows a difference in education expenditure of $20.9 \%$ after controlling for labor and non-labor income and the stock of durable goods. This is still two-thirds of the total causal effect. When the housing variables are included, there is actually a slight increase from the total causal effect estimated previously.

To conclude, differences in income, the stock of durable goods, and the housing situation can explain at most one third of the total effect, but do not seem to be the main mechanism. There still seems something else to be going on that was induced by displacement of the parents. 


\subsection{Employment status of parents}

Another mechanism to explore is whether differences in the employment status of the parents cause the education expenditure difference. If both parents are working, parents may not have the time to help their children learn and therefore spend more on books and school materials to make up for less personal support (Houtenville and Smith Conway 2008). The descriptive statistics in Table 12 show that displaced parents are less likely to be employed. This mechanism could therefore explain the difference in education expenditure.

I test this hypothesis by including indicator variables for employment status of both parents (or a single parent), the spouse of the household head, and if no parent is employed in Table 13. Interaction terms of the employment indicators with displacement are included as well. Again the mean of the non-movers of each employment variable is subtracted from the indicator variable to interpret the displacement dummy as the aforementioned counterfactual. In the three following columns I add one dummy variable and the interaction term at a time. None of these coefficients is significant at a traditional level as can be seen in Table 13.

As with income, the coefficients show that only a small portion of the difference in education expenditure can be explained by the employment status of the parents, at most about one tenth in the last regression. The main mechanism through which displacement affects education expenditure is still undetected.

\subsection{Preferences, uncertainty, and financial constraints}

In summary, neither income, the durable goods level, the housing situation nor the employment status of the parents are able to account for the majority of the difference in education expenditure. The natural question is then: How does the effect come about? Unfortunately, I am not able to fully answer this question. This section discusses additional explanations.

A possible explanation is that displaced households are able to buy cheaper school materials and textbooks or share the supplies with other families. Displaced households in an area may build networks to help each other. However, it is hard to imagine that displaced households find a way to save on education expenditure that households who did not move during the war do not find, especially with their social network in place. The non-movers in Bosnia and Herzegovina are not exactly rich to pass up a possibility to save.

Voors et al. (2012) present evidence from field experiments in Burundi showing that exposure to violence affects preferences. In detail they report more altruistic behavior

Table 12 Descriptive statistics: parent's employment status

\begin{tabular}{lcccc}
\hline & All & Not moved & Displaced & Difference \\
\hline Both Parents Employed & 0.29 & 0.30 & 0.23 & $-0.07^{* * *}$ \\
Spouse of HHH Employed & 0.28 & 0.29 & 0.23 & $(0.026)$ \\
No Parent Employed & 0.34 & 0.30 & $0.06^{* *}$ \\
& & & & $(0.026)$ \\
Observations & 1,901 & 1,541 & 360 & $0.17^{* * *}$ \\
\hline
\end{tabular}

Standard errors in parenthesis.

Significance levels: ${ }^{*}: 10 \%{ }^{* *}: 5 \%{ }^{* * *}: 1 \%$. 
Table 13 Regression output: parent's employment status

\begin{tabular}{|c|c|c|c|c|}
\hline & \multicolumn{4}{|c|}{ Log. of education expenditure } \\
\hline & (1) & (2) & (3) & (4) \\
\hline \multirow[t]{2}{*}{ Displaced Family } & $-0.281^{* * *}$ & $-0.290^{* * *}$ & $-0.276^{* * *}$ & $-0.274^{* * *}$ \\
\hline & $(0.0687)$ & $(0.0682)$ & $(0.0696)$ & $(0.0689)$ \\
\hline \multirow[t]{2}{*}{ Both Parents Employed ${ }^{1}$} & 0.097 & & & 0.056 \\
\hline & $(0.0674)$ & & & $(0.0723)$ \\
\hline Displaced Family $\times$ & 0.165 & & & 0.203 \\
\hline Both Parents Employed ${ }^{1}$ & $(0.1529)$ & & & $(0.1689)$ \\
\hline \multirow[t]{2}{*}{ Spouse Employed ${ }^{1}$} & & 0.095 & & \\
\hline & & $(0.0676)$ & & \\
\hline Displaced Family $x$ & & 0.062 & & \\
\hline Spouse Employed' & & $(0.1476)$ & & \\
\hline \multirow[t]{2}{*}{ No Parent Employed ${ }^{1}$} & & & $-0.147^{* *}$ & $-0.129^{*}$ \\
\hline & & & $(0.0705)$ & $(0.0756)$ \\
\hline Displaced Family $\times$ & & & 0.017 & 0.099 \\
\hline No Parent Employed ${ }^{1}$ & & & $(0.1340)$ & $(0.1470)$ \\
\hline F-test & $9.74^{* * *}$ & $9.34^{* * *}$ & $8.08^{* * *}$ & $6.14^{* * *}$ \\
\hline Controls & Yes & Yes & Yes & Yes \\
\hline Municipality FE & Yes & Yes & Yes & Yes \\
\hline No. Observations & 1,901 & 1,901 & 1,901 & 1,901 \\
\hline R-squared & 0.202 & 0.200 & 0.202 & 0.204 \\
\hline
\end{tabular}

Standard errors clustered at the household level in parenthesis.

Significance levels: ${ }^{*}: 10 \% * *: 5 \% * * *: 1 \%$.

Control variables include number of children in $\mathrm{HH}$ enrolled, education of $\mathrm{HHH}$, age of $\mathrm{HHH}$ and dummy variables for being the oldest child and females. "F-test" results from a test of joint significance of displacement and all its interactions.

${ }^{1}$ Measured as the difference to the mean of non-movers.

towards neighbors, more risk taking, and a higher discount rate. For my purpose the higher discount rate is of special interest. If displaced households were more exposed to violence than non-movers, as can be expected, then displaced parents could have a higher discount rate than parents who were not displaced. Individuals with a higher discount rate would invest less in projects that generate a payoff in the future - such as education. Unfortunately, with the crude consumption data available, such a hypothesis can not be tested seriously.

Two other potential explanations come to mind. First, displaced households face a lot of uncertainty about the future and try to prepare themselves by cutting down spending on every non-vital position, which includes education expenditure. In a simple two period model, an agent with convex marginal utility reduces consumption in the first period if the risk of period 2 income increases. Kimball (1990) calls this phenomenon prudence and defines it as "the propensity to prepare and forearm oneself in the face of uncertainty". In 2001 the restitution of property to internally displaced households and the possibility to return to their homes from before the war was still an issue in Bosnia and Herzegovina. Many displaced households probably faced a highly uncertain future. On the other hand one could argue that increased uncertainty through displacement prompts households to invest more in highly mobile assets, such as human capital, which they could take with them if they ever had to change location again.

The second potential explanation are financial constraints. Displaced households could face tighter financial constraints due to the loss of their social network for credit or the lack of property they could use as collateral. Unfortunately, financial assets are not 
included in the survey to infer about financial constraints. Even if financial constraints are not binding now, the expectation that they will bind in the future would already induce households cut back on expenditures today (Deaton 1991).

However, I am not able to give a full explanation how the difference in education expenditure comes about. A change in the discount rate of displaced households, increased risk, and financial constraints are consistent with the findings of this paper, but other channels through which displacement works can not be ruled out in general.

\section{Conclusion}

This paper contributes to the literature on the consequences of violent conflicts by looking at the effect of displacement, in the sense of forced migration, on investment in education. I find a robust statistical relationship between the displacement status of parents and the amount spent on the education of their children. The reduction of education expenditure through displacement is in the range of 20 to $30 \%$ compared to parents who did not move during the war. The estimated difference in education expenditure is robust to many specifications and a series of tests indicate that selection bias is not the source of the result. Nearest-neighbor matching on covariates finds quantitatively similar effects.

A number of channels of how displacement might affect education expenditure are discussed. Differences in income and durable goods levels can explain at most one third of the baseline result. A lower ownership rate of housing among displaced households also fails to explain the main finding. The employment of parents and support from outside the household can also be ruled out as the main mechanisms.

I further discuss recent experimental findings on the effect of exposure to violence on preferences, the hypothesis that the displaced households face more uncertainty about the future, or more rigid financial constraints than non-movers. That would lead them to cut back spending on every non-vital position, including the education of their children.

More work needs to be done to fully understand how violent conflict influences peoples lives. Research has shown negative consequences of exposure to violence and displacement, but how exactly the changes in economic outcomes come about is not fully understood yet.

\section{Endnotes}

${ }^{1}$ The term "displacement" refers to forced migration and is different to job loss, which the labor literature often refers to as displacement.

${ }^{2}$ As Das et al. (2013) show, when parents expect to receive additional resources, they substitute out of their own educational expenditure and therefore the total educational inputs available to students do not increase much. This substitution is likely responsible for the failure to find positive effects in previous experimental studies.

${ }^{3} \mathrm{~A}$ problem for the estimation of causal effects emerges as the often used difference-in-difference approach between birth cohorts of treatment and control regions does not account for non-random wartime displacement. This generates a sample correlation between outcomes and conflict intensity that is not the causal effect of exposure to conflict.

${ }^{4}$ Detailed reports about conditions at schools during the academic year 2000-01 are, to my knowledge, not available.

${ }^{5}$ Croats are hardly found as displaced people in the data, because households of Croats who found them self in Serb territory likely moved to the - then newly formed - Republic of Croatia (IDMC 2009). I will therefore focus on Bosniaks and Serbs from now on. 


\section{${ }^{6}$ This is also true for the larger sample of all household heads and their spouses in the LSMS data set, not just the ones with children in school that is used here.}

\section{Competing interests}

The IZA Journal of Labor \& Development is committed to the IZA Guiding Principles of Research Integrity. The author declares that he has observed these principles.

\section{Acknowledgements}

The research presented in this article was conducted as part of my PhD dissertation at Simon Fraser University. My senior supervisor, Anke Kessler, contributed by providing comments on research design and exposition, while the junior supervisors, Simon Woodcock and Chris Muris, help with comments on the exposition of the research. I also thank Gustavo Bobonis, Alex Karaivanov, Krishna Pendakur, and conference participants at the Atlantic Summer Conference on Public Policy Research, the Development Conference of the German Economic Association, the conference of the European Association of Labour Economists, seminar participants at Johannes Kepler University, the editor (Hartmut Lehmann), and four anonymous referees for helpful comments. All remaining errors are mine.

Received: 31 March 2014 Accepted: 11 June 2014

Published: 22 July 2014

\section{References}

Akresh R, de Walque D (2008) Armed Conflict and Schooling: Evidence from the 1994 Rwandan Genocide. HiCN Working Paper 47. http://www.hicn.org/wordpress/wp-content/uploads/2012/06/wp47.pdf. Accessed 23 Jun 2014 Angrist J, Pischke J (2009) Mostly Harmless Econometrics. Princeton University Press, Princeton NJ

Bauer T, Braun S, Kvasnicka M (2013) The Economic Integration of Forced Migrants: Evidence from Post-War Germany. Econ J 123:998-1024

Bellows J, Miguel E (2009) War and Local Collective Action in Sierra Leone. J Public Econ 93:1144-1157

Chamarbagwala R, Morán H (2009) The Human Capital Consequences of Civil War: Evidence from Guatemala. HiCN Working Paper:59. http://www.hicn.org/wordpress/wp-content/uploads/2012/06/wp59.pdf. Accessed 23 Jun 2014

Das J, Dercon S, Habyarimana J, Krishnan P, Muralidharan K, Sundararaman V (2013) School Inputs, Household Substitution, and Test Scores. Am Econ J Appl Econ 5:29-57

Dahlman C, Tuathail G (2005) Broken Bosnia: The localized geopolitics of displacement and return in two Bosnian places. Ann Assoc Am Geograph 95:644-662

Deaton A (1991) Savings and Liquidity Constraints. Econometrica 59:1221-1248

EU (2008) Institutional and Capacity Building of Bosnia and Herzegovina Education System. http://www.cep.edu.rs/sites/ default/files/Education_Strategy_2008_-_2015.pdf. Accessed 23 Jun 2014

Fiala N (2009) The Consequences of Forced Displacement in Northern Uganda. HiCN Working Paper:65. http://www.hicn. org/wordpress/wp-content/uploads/2012/06/wp65.pdf. Accessed 23 Jun 2014

Hanushek E (2003) The Failure of Input-Based Schooling Policies. Econ J 113:64-98

Houtenville A, Smith Conway K (2008) Parental Effort, School Resources, and Student Achievement. J Hum Resour 43:437-453

IDMC (2009) A profile of the internal displacement situation: Croatia. http://unpan1.un.org/intradoc/groups/public/ documents/untc/unpan016823.pdf. Accessed 23 Jun 2014

Justino P (2011) Violent Conflict and Human Capital Accumulation. HiCN Working Paper:99. http://www.hicn.org/ wordpress/wp-content/uploads/2012/06/wp99.pdf. Accessed 23 Jun 2014

Kennedy P (1981) Estimation with correctly interpreted dummy variables in semilogarithmic equations. Am Econ Rev 71:801

Kimball M (1990) Precautionary Savings in the Small and in the Large. Econometrica 58:53-73

Kondylis F (2010) Conflict Displacement and Labour Market Outcomes in Post-War Bosnia and Herzegovina. J Dev Econ 93:235-248

León G (2012) Civil conflict and Human Capital Accumulation: The Long Term Consequences of Political Violence in Perú. J Hum Resour 47:991-1022

Mappes-Niediek N (2009) Die Ethno-Falle. Christoph Links Verlag, Berlin

Merrouche O (2006) The Human Capital Cost of Landmine Contamination in Cambodia. HiCN Working Paper:25. http:// www.hicn.org/wordpress/wp-content/uploads/2012/06/wp25.pdf. Accessed 23 Jun 2014

MHHR (Ministry for Human Rights and Refugees) (2003) Comparative Indicators on Refugees, Displaced Persons and Returnees, Property Law Implementation, and Reconstruction in BiH from 1991 to 30 June 2003. http://www.mhrr. gov.ba/PDF/LjudskaPrava/common\%20core\%20document\%20BH-rev-ENGLISH.pdf. Accessed 23 Jun 2014

Mooney E (2005) Access to Education for Internally Displaced Children. The Brookings Institution-University of Bern. http://www.brookings.edu/fp/projects/idp/20050111_mooney.pdf. Accessed 23 Jun 2014

OECD, Mission to Bosnia and Herzegovina (2006) Action Plan on School Enrolment and Completion in Bosnia and Herzegovina. http://www.oscebih.org/documents/osce_bih_doc_2006092510260492eng.pdf. Accessed 23 Jun 2014

Pivovarova M, Swee E (2012) Quantifying The Microeconomic Effects of War: How Much Can Panel Data Help? HiCN Working Paper 116. http://www.hicn.org/wordpress/wp-content/uploads/2012/06/HiCN-WP-116.pdf. Accessed 23 Jun 2014

Rahim A, Jaimovich D, Ylönen A (2013) Forced displacement and behavioral change: An empirical study of returnee households in the Nuba Mountains. HiCNWorking Paper 157. http://www.hicn.org/wordpress/wp-content/uploads/ 2012/06/HiCN-WP-157_1.pdf. Accessed 23 Jun 2014

Rodriguez C, Sanchez F (2009) Armed Conflict Exposure, Human Capital Investments and Child Labor: Evidence from Colombia. HiCNWorking Paper 68. http://www.hicn.org/wordpress/wp-content/uploads/2012/06/wp68.pdf. Accessed 23 Jun 2014 
Sarvimäki M, Uusitalo R, Jäntti M (2009) Long-Term Effects of Forced Migration. IZA Discussion Paper 4003. http://ftp.iza. org/dp4003.pdf. Accessed 23 Jun 2014

Silber L, Little A (1996) The Death of Yugoslavia. Penguin Books, London

State Agency for Statistics of BiH, Statistical Institute of the Federation of BiH, Republika Srpska Statistical Institute and The World Bank (2001) Living Standard Measurement Survey - Bosnia and Herzegovina. http://tinyurl.com/bdetznv. Accessed 23 Jun 2014

Shemyakina O (2011) Education and Armed Conflict in Tajikistan. HiCN Working Paper 106. http://www.hicn.org/ wordpress/wp-content/uploads/2012/06/wp1061.pdf. Accessed 23 Jun 2014

Swee E (2009) On War and Schooling Attainment: The Case of Bosnia and Herzegovina. HiCN Working Paper 57. http:// www.hicn.org/wordpress/wp-content/uploads/2012/06/wp57.pdf. Accessed 23 Jun 2014

Swee E (2010) Together or Separate? Post-conflict Partition, Ethnic Homogenization, and the Provision of Public Schooling. http://individual.utoronto.ca/swee/ethnic11.pdf. Accessed 23 Jun 2014

Tuathail G, O'Loughlin J (2009) After Ethnic Cleansing: Return Outcomes in Bosnia-Herzegovina a Decade Beyond War. Ann Assoc Am Geograph 99:1045-1053

UNESCO (1996) Review of the education system in the Federation of Bosnia and Herzegovina. http://unesdoc.unesco. org/images/0011/001144/114461eo.pdf. Accessed 23 Jun 2013

UNESCO (1997) Review of the education system in the Republika Srpska - Bosnia and Herzegovina. http://unesdoc. unesco.org/images/0010/001092/109215eo.pdf. Accessed 23 Jun 2014

UNHCR (2009) Global Report 2009. http://www.unhcr.org/gr09. Accessed 23 Jun 2014

van Garderen K, Shah C (2002) Exact interpretation of dummy variables in semilogarithmic equations. Econometrics J 5:149-159

Voors M, Nillesen E, Verwimp P, Bulte E, Lensink R, van Soest D (2012) Violent Conflict and Behavior: A Field Experiment in Burundi. American Economic Review 102:941-964

doi:10.1186/2193-9020-3-12

Cite this article as: Eder: Displacement and education of the next generation: evidence from Bosnia and

Herzegovina. IZA Journal of Labor \& Development 2014 3:12.

\section{Submit your manuscript to a SpringerOpen ${ }^{\circ}$ journal and benefit from:}

$\checkmark$ Convenient online submission

- Rigorous peer review

- Immediate publication on acceptance

- Open access: articles freely available online

- High visibility within the field

- Retaining the copyright to your article

Submit your next manuscript at $\gg$ springeropen.com 